ISSN 2087-3336 (Print) | 2721-4729 (Online)

TEKNOSAINS: Jurnal Sains, Teknologi dan Informatika

Volume 8, Nomor 1, Januari 2021, hlm. 54-62

http://jurnal.sttmcileungsi.ac.id/index.php/tekno

DOI: 10.37373

\title{
PENGARUH VARIASI SUDUT KAMPUH V TERHADAP SIFAT MEKANIS PADA SAMBUNGAN LAS ALUMINIUM 5083 ENGINE GIRDER KAPAL LAUT
}

\section{THE EFFECT OF KAMPUH V ANGLE VARIATION ON MECHANICAL PROPERTIES OF ALUMINUM 5083 ENGINE GIRDER SEA WELDING CONNECTIONS}

\author{
Joni Arif*, Koswara \\ Program Studi Magister Teknik Mesin, Institut Sains dan Teknologi Nasional, Jakarta, Indonesia \\ *Koresponden email: joniarif11@gmail.com
}

\begin{abstract}
ABSTRAK
Material Aluminium AA 5083-H116 sering digunakan dalam industri perkapalan terutama sebagai bahan material kapal jenis Aluminium, karena memiliki sifat mekanik dan memiliki pertahanan korosi yang sangat baik. Aluminium ini digunakan juga sebagai engine girder kapal laut. AA 5083-H116 merupakan paduan Aluminium Magnesium dengan kemampuan las yang baik. Penelitian ini bertujuan untuk membandingkan sambungan las AA 5083-H116 dengan memvariasikan sudut bevel las $60^{\circ}, 70^{\circ}$, $80^{\circ}, 90^{\circ}$ dengan arus $105 \mathrm{~A}, 127 \mathrm{~A}, 130 \mathrm{~A}$. Proses pengelasan metal inert gas (MIG) menggunakan filler metal AWS A5.10 ER5183. Kekuatan Impact tertinggi diperoleh pada sudut kemiringan $60^{\circ}$ sebesar $0,42 \mathrm{~J} / \mathrm{mm}^{2}$. Sedangkan uji kekerasan logam las sebesar 74,75 HV dan nilai kekerasan logam dasar sebesar 88,325 HV.
\end{abstract}

Kata Kunci: Aluminium AA 5083-H116, las MIG, double V, variasi sudut kampuh.

\section{ABSTRACT}

The aluminum AA 5083-H116 is widely used in the shipping industry, especially as a material for ship construction, because it has good mechanical properties and corrosion resistance. This aluminum is also used as a marine engine girder. AA 5083 is an aluminum-magnesium alloy with good weldability. This study aims to compare welding joints AA 5083-H116 by varying the angle of the welding bevel 600, 700, 800, 900 with a current of $105 \mathrm{~A}, 127 \mathrm{~A}, 130 \mathrm{~A}$. The metal inert gas (MIG) welding process uses filler metal AWS A5.10 ER 5183. The highest Impact strength is obtained at a 600 Bevel angle of $0.42 \mathrm{~J} / \mathrm{mm} 2$. Meanwhile, the hardness test on the weld metal is $74.75 \mathrm{HV}$ and the hardness value on the base metal is $88.325 \mathrm{HV}$.

Keywords: Aluminum AA 5083-H116, MIG welding, double V, a variation of seam angles

\section{PENDAHULUAN}

Pengelasan adalah penyambungan 2 buah plat secara permanen untuk menggabungkan material yang berbeda seperti logam, paduan atau plastik, bersama-sama pada permukaan yang bersentuhan 
dengan metode panas atau metode tekanan. Ada beberapa faktor yang mempengaruhi pengelasan di antaranya cara pembuatan kontruksi pengelasan dan spesifikasi dari pabrik [1]. Untuk mengetahui sifat logam dilakukan pengujian spesimen di antaranya pengujian tarik impact, hardness, microstructure dan komposisi kimia [2].

Pengelasan MIG sering digunakan untuk plat tipis pada paduan logam dan baja anti karat [3]. AA 5083-H116 banyak dipakai di industri transportasi laut maupun darat seperti gerbong kereta api, kapal laut dan pesawat terbang. Untuk mengetahui sifat-sifat logam tersebut, dilakukan beberapa pengujian, misalnya pengujian tarik, uji impact, uji kekerasan, uji struktur mikro, dan komposisi kimia. Tujuan penelitian untuk mengetahui pengaruh variasi sudut yang berbeda pada pengelasan MIG (metal inert gas) terhadap sifat mekanis yang menggunakan AWS A5.10 ER5183 [4]

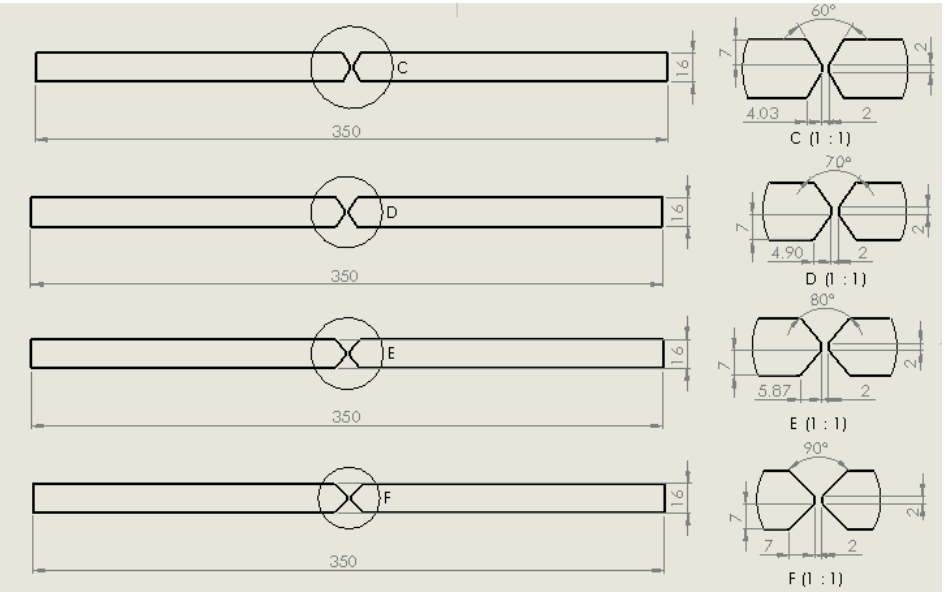

Gambar 1. Ukuran dan bentuk sudut kampuh.

\section{METODE}

Metode penelitian diawali persiapan material AA 5083-H116 yang mengacu pada WPS sudut kampuh $\left(60^{\circ}, 70^{\circ}, 80^{\circ}, 90^{\circ}\right)$. Untuk pengujian peneliti menggunakan sudut kampuh $\left(60^{\circ}, 70^{\circ}, 80^{\circ}, 90^{\circ}\right)$ yang berbeda, dasar pengambilan variable sudut kampuh $\left(60^{\circ}, 70^{\circ}, 80^{\circ}, 90^{\circ}\right)$ mengacu pada WPS untuk melihat hasil pengelasan, selanjutnya melakukan pemotongan bahan untuk spesimen, dan yang terakhir pengujian di laboratorium [5].

Bahan material digunakan dalam penelitian adalah bahan material aluminium AA 5083-H116 [6]. Ukuran plat yang digunakan $350 \mathrm{~mm} \times 350 \mathrm{~mm} \times 16 \mathrm{~mm}$. Pengelasan dilakukan di perusahan asal plat tersebut dengan menggunakan sudut kampuh $\left(60^{\circ}, 70^{\circ}, 80^{\circ}, 90^{\circ}\right)$. Jumlah bahan material yang dibutuhkan 8 lembar. Pada gambar 1 dan 2 yang menunjukkan ukuran dan bentuk sudut kampuh.

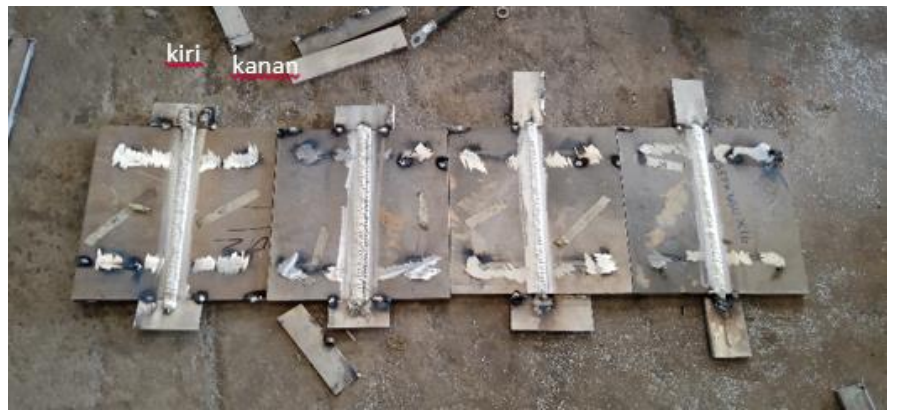

Gambar 2. Sudut kampuh $60^{\circ}, 70^{\circ}, 80^{\circ}, 90^{\circ}$.

\section{HASIL DAN PEMBAHASAN}

Hasil pengkajian dari literatur dan hasil pengujian penelitian yang dilakukan ditempat BPPTBalai Besar Teknologi Kekuatan Struktur (B2TKS) dengan menggunakan beberapa pengujian yang dilakukan. 


\subsection{Pengujian komposisi kimia.}

Pada pengujian tabel 1 menunjukan bahwa komposisi kimia pada material Aluminium AA 5083H116 dengan standar uji SNI 19-0409-1198 dengan nama mesin frank finotest yang digunakan pada penelitian [7] [8]

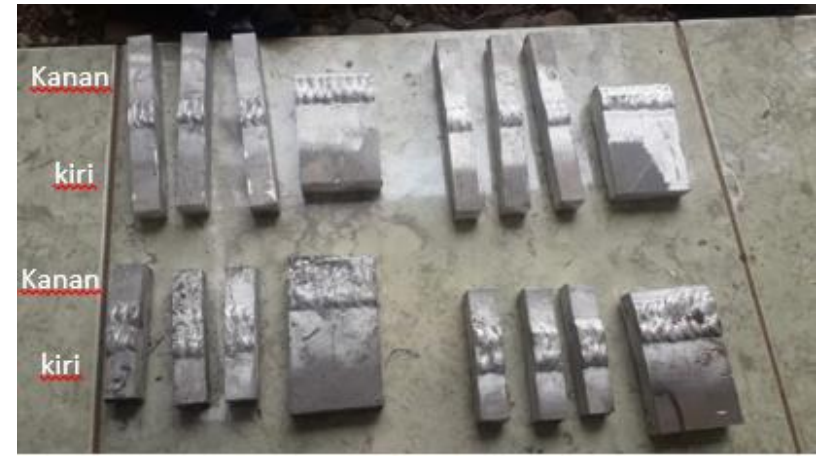

Gambar 3. Bentuk spesimen pengujian $60^{\circ}, 70^{\circ}, 80^{\circ}, 90^{\circ}$.

Tabel 1. Komposisi kimia pengujian.

\begin{tabular}{ccc}
\hline No. & Unsur & $\begin{array}{c}\text { Nilai Kandungan } \\
\text { Unsur }(\% \text { berat })\end{array}$ \\
\hline $\mathbf{1}$ & $\mathrm{Al}$ & 94,7 \\
$\mathbf{2}$ & $\mathrm{Si}$ & 0,16 \\
$\mathbf{3}$ & $\mathrm{Fe}$ & 0,355 \\
$\mathbf{4}$ & $\mathrm{Cu}$ & 0,0185 \\
$\mathbf{5}$ & $\mathrm{Mn}$ & 0,566 \\
$\mathbf{6}$ & $\mathrm{Mg}$ & 4,01 \\
$\mathbf{7}$ & $\mathrm{Cr}$ & 0,0819 \\
$\mathbf{8}$ & $\mathrm{Zn}$ & 0,119 \\
$\mathbf{9}$ & $\mathrm{Ni}$ & 0,005 \\
$\mathbf{1 0}$ & $\mathrm{Ti}$ & 0,0037 \\
$\mathbf{1 1}$ & $\mathrm{Pb}$ & 0,005 \\
$\mathbf{1 2}$ & $\mathrm{V}$ & 0,0046 \\
\hline
\end{tabular}

\subsection{Pengujian impact.}

Dalam pengujian impact peneliti melihat keuletan dan kegetasan pada Aluminium AA 5083-H116 dengan mengkombinasikan sudut kampuh pada setiap spesimen yang menggunakan standar Internasional JIS Z 2242. Bila menggunakan Standar Nasional Indonesia menggunakan SNI 07-67322002 dan mesin uji PSW 300 didapat hasil sesuai dengan tabel 2 [9].

Tabel 2. Test impact report.

\begin{tabular}{cccccccc}
\hline \multirow{2}{*}{ No } & \multicolumn{2}{c}{ Dimensi $(\mathrm{mm})$} & \begin{tabular}{c} 
Luas \\
\cline { 2 - 3 }$\left(\mathrm{mm}^{2}\right)$
\end{tabular} & $\begin{array}{c}\text { Temp. } \\
\left({ }^{\circ} \mathrm{C}\right)\end{array}$ & $\begin{array}{c}\text { Energi } \\
(\mathrm{J})\end{array}$ & $\begin{array}{c}\text { Kuat Impact } \\
\left(\mathrm{J} / \mathrm{mm}^{2}\right)\end{array}$ & ket \\
\hline 1 & 10,11 & 8,23 & 83 & Ruang & 35 & 0.42 & $60^{\circ}$ \\
2 & 10,10 & 8,30 & 84 & Ruang & 30 & 0.36 & $60^{\circ}$ \\
3 & 10,20 & 8,19 & 84 & Ruang & 40 & 0.48 & $60^{\circ}$ \\
4 & 10,19 & 8,02 & 82 & Ruang & 15 & 0.18 & $70^{\circ}$
\end{tabular}




\begin{tabular}{cccccccc}
5 & 10,36 & 8,16 & 85 & Ruang & 18 & 0.21 & $70^{\circ}$ \\
6 & 10,51 & 8,40 & 88 & Ruang & 45 & 0.51 & $70^{\circ}$ \\
7 & 10,20 & 8,21 & 84 & Ruang & 25 & 0.30 & $80^{\circ}$ \\
8 & 10,15 & 8,04 & 82 & Ruang & 27 & 0.33 & $80^{\circ}$ \\
9 & 10,23 & 8,04 & 82 & Ruang & 22 & 0.27 & $80^{\circ}$ \\
10 & 10,33 & 8,30 & 86 & Ruang & 30 & 0.35 & $90^{\circ}$ \\
11 & 10,42 & 8,29 & 86 & Ruang & 21 & 0.24 & $90^{\circ}$ \\
12 & 10,46 & 8,47 & 89 & Ruang & 25 & 0.28 & $90^{\circ}$ \\
\hline
\end{tabular}

Keterangan: Untuk nilai kuat impact didapat dari rumus $H I=\frac{E}{A}$

- HI: Kuat impact $\left(\mathrm{J} / \mathrm{mm}^{2}\right)$.

- E: Usaha memetahkan untuk mematahkan benda uji (J).

- A: Luas penampang di luar takikan $\left(\mathrm{mm}^{2}\right)$.

Dengan menggunakan data pada tabel 2 bisa dicari kuat impact rata-rata setiap sudut kampuh. Adapun hasilnya dapat dilihat pada tabel 3.

Tabel 3. Rata rata kuat impact.

\begin{tabular}{ccc}
\hline No & Sudut kampuh & Rata-rata $\left(\mathrm{J} / \mathrm{mm}^{2}\right)$ \\
\hline 1 & $60^{\circ}$ & 0.42 \\
2 & $70^{\circ}$ & 0.30 \\
3 & $80^{\circ}$ & 0.30 \\
4 & $90^{\circ}$ & 0.29 \\
\hline
\end{tabular}

Dengan menggunakan tabel 3, dapat dicari persentase kuat impact vs sudut kampuh pengujian dan dengan tabel 4 dapat dicari persentase rata-rata kuat impact pada setiap kampuh dalam bentuk grafik pada gambar 3 dan 4 .

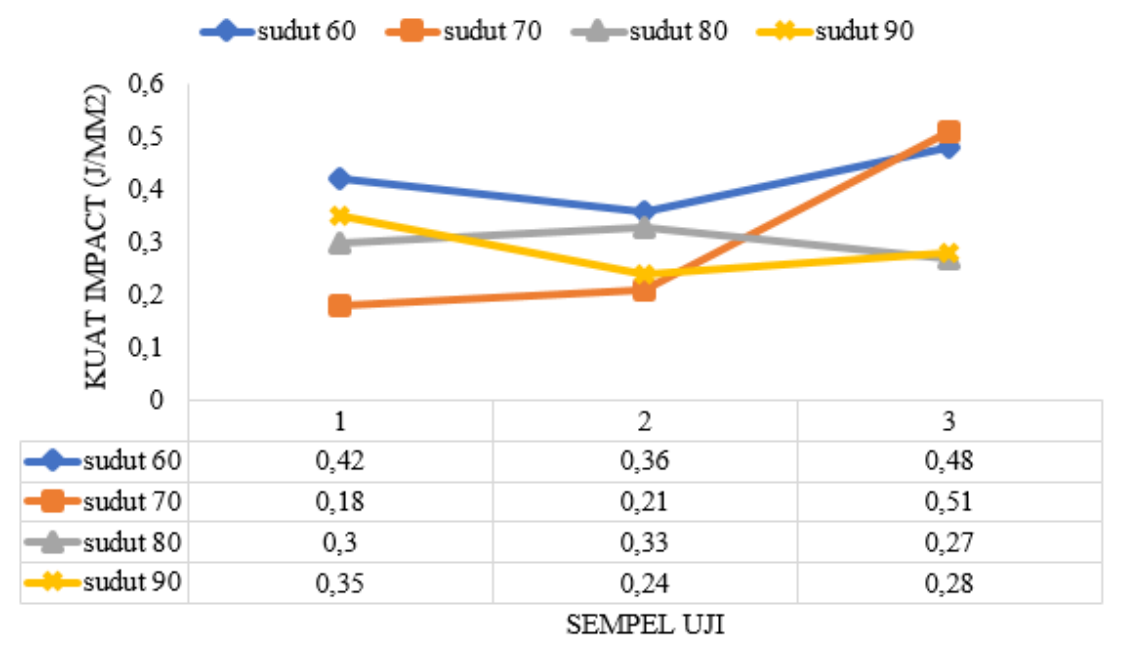

Gambar 4. Grafik kuat impact pada semua sudut kampuh

Dari gambar 4 dapat disimpulkan bahwa pada sudut kampuh $60^{\circ}$, energi impactnya sangat tinggi yaitu sebesar $0.42 \mathrm{~J} / \mathrm{mm}^{2}$.

\subsection{Pengujian hardness}

Pengujian hardness menghasilkan nilai kekerasan seperti dapat dilihat pada tabel 4. Nilai tersebut didapat setelah sebelumnya dilakukan variasi arus kuat listrik dengan 3 kali pengelasan pada setiap kampuh. Dari tabel 4 didapatkan nilai kekerasan di setiap sisi yang bervariasi. Pengelasan dilakukan 
sebanyak 3 kali [10]. Dengan kuat arus 105 A, 127 A, dan 130 A dan didapat beberapa hasil dengan menggabungkan setiap nilai kekerasan setiap bagian didapat grafik pada gambar 5 .

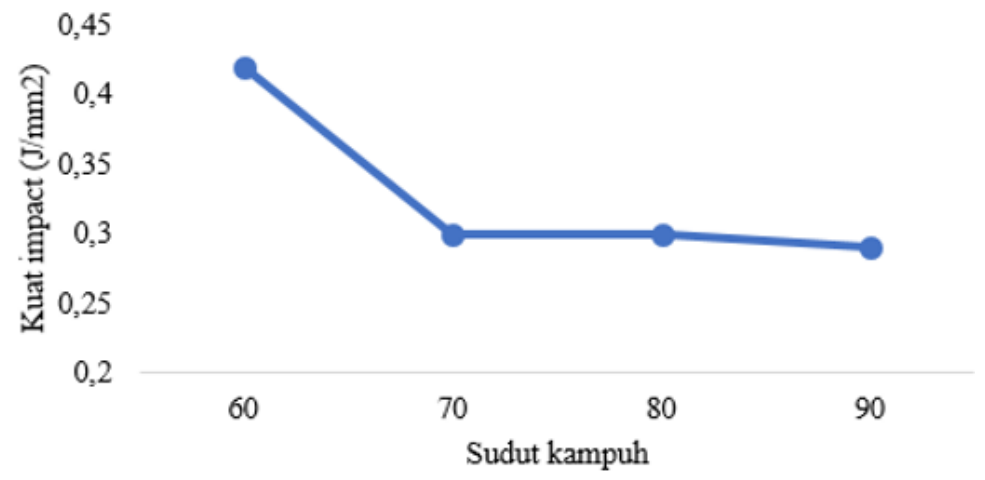

Gambar 5. Grafik rata rata kuat impact.

Tabel 4 hasil dari pengujian hardness dengan mengambil sampel di 20 titik. Pengujian dilakukan di beberapa daerah diantaranya base metal kanan (4), HAZ kanan (4), Weld Metal (4), HAZ kiri (4), dan base metal kiri (4). Dengan menggunakan metode pengujian hardness mode micro vickers beban $5 \mathrm{~kg}$ selama 10 detik [11][12].

Tabel 4. Hasil uji kekerasan pada sampel pengelasan dengan sudut $60^{\circ}$

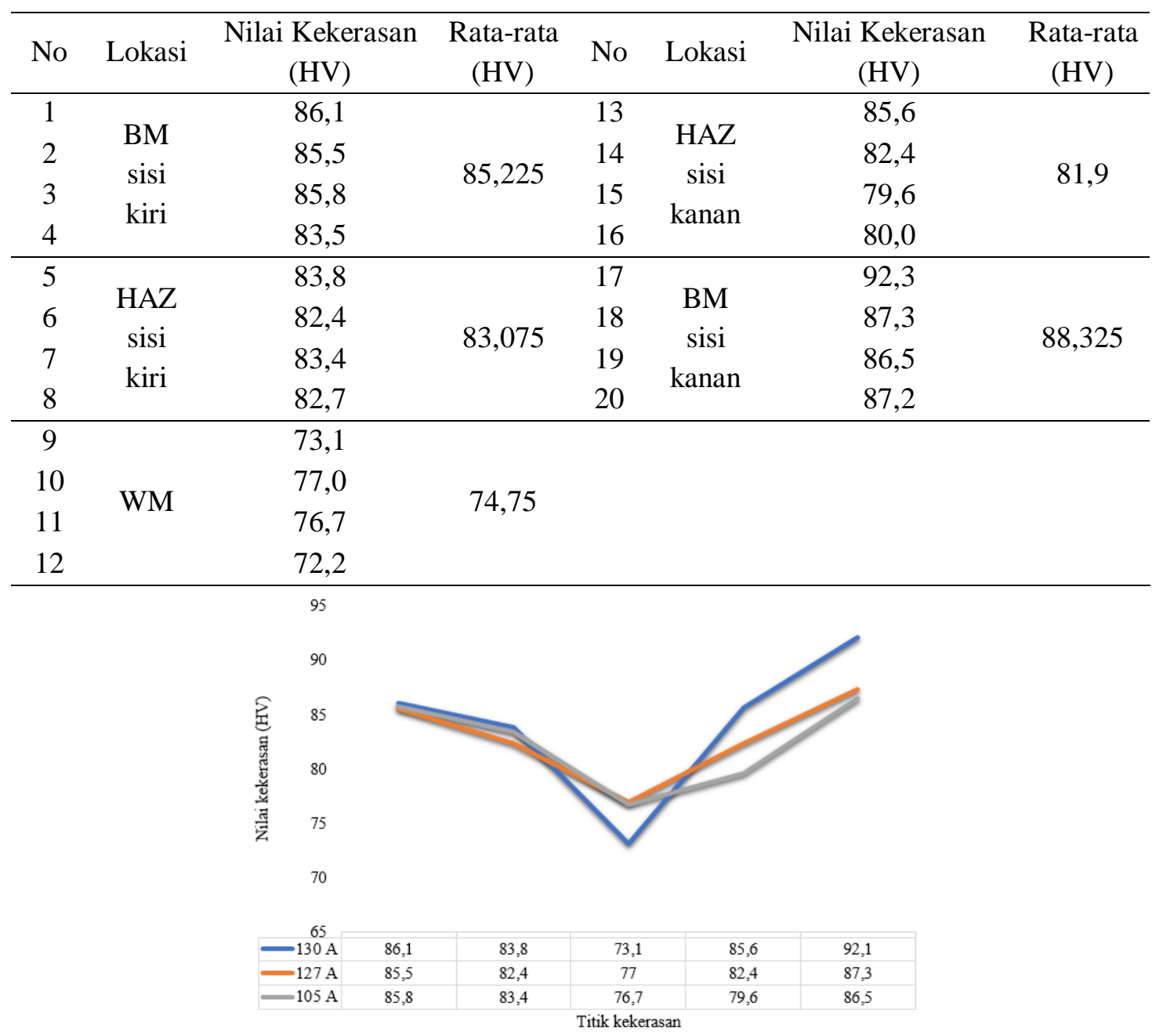

Gambar 6. Grafik nilai kekerasan vs Ampere 


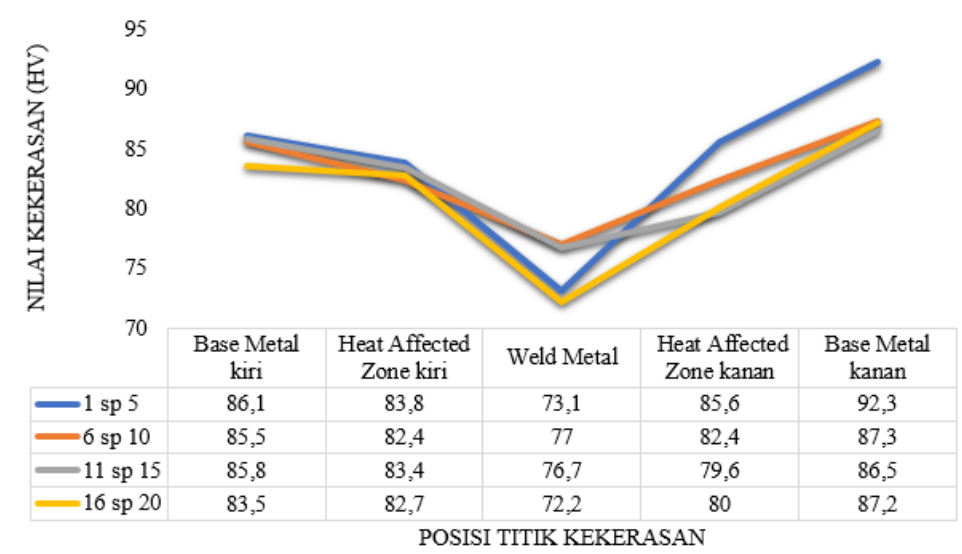

Gambar 7. Grafik uji kekerasan

Pada gambar 7 nilai kekerasan menurun berada pada daerah weld metal, dibanding dengan di daerah base metal [16]. Hal ini menunjukkan bahwa weld metal lebih ulet dibanding base metal [13]. Gambar 6 menunjukkan grafik nilai rata-rata setiap daerah kekerasan yang akan dibandingkan dengan standar seperti dilihat pada tabel 4.

ASM handbook Aluminum Alloy:Metal, Nonferrous Metal menunjukkan standar hardness vickers sebesar 96 HV. Sedangkan di bagian weld metal nilai rata-ratanya, yaitu $74.75 \mathrm{HV}$ dan nilai kekerasan tertinggi di base metal bagian kanan dengan nilai rata-ratanya, yaitu $88.325 \mathrm{HV}$. Maka dapat di analisis bahwa base metal tidak terpengaruh perubahan temperatur. sedangkan di bagian weld metal terdapat perubahan temperatur [14].

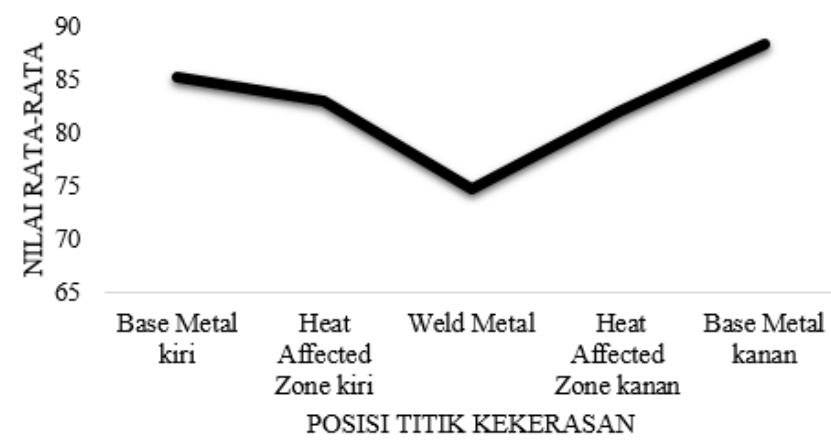

Gambar 8. Rata-rata kekerasan

\subsection{Pengujian metalografi}

Pengujian metalografi pada material Aluminium AA 5083-H116 dengan pengambilan struktur mikro pada daerah base metal, HAZ dan weld metal, untuk mengetahui perubahan struktur mikro pada pengelasan [15].

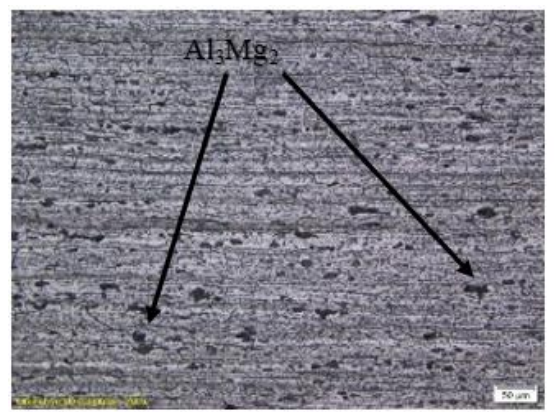

Pembesaran $200 \mathrm{x}$

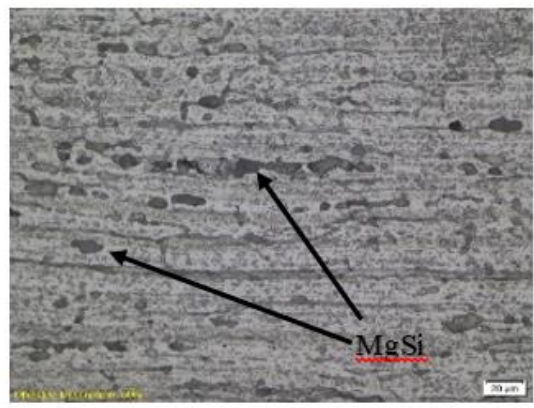

Pembesaran $500 \mathrm{x}$

Gambar 9. Struktur mikro pada base metal 


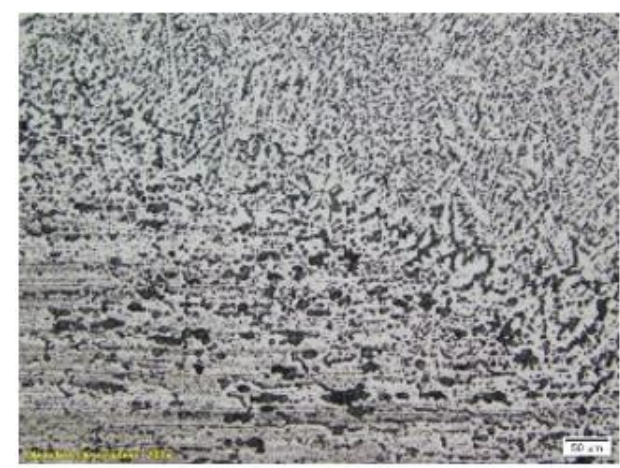

Pembesaran $200 x$

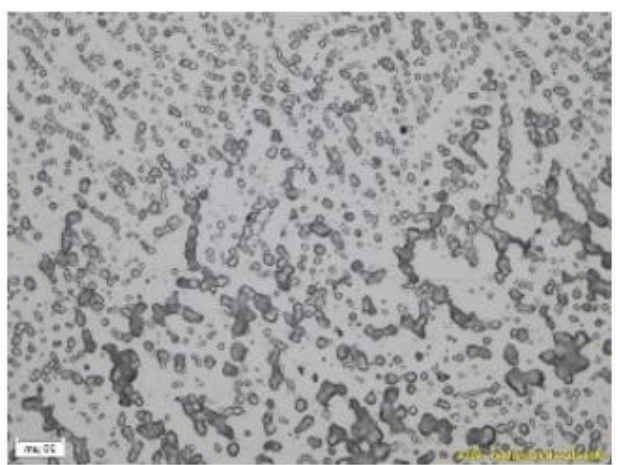

Pembesaran $500 \mathrm{x}$

Gambar 10. Struktur mikro pada Haz

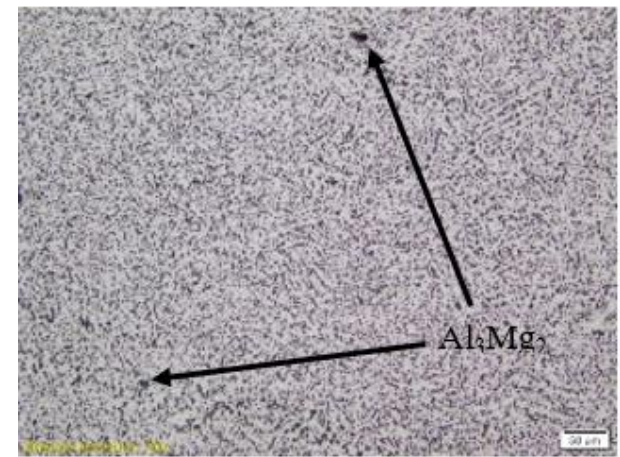

Pembesaran $200 \mathrm{x}$

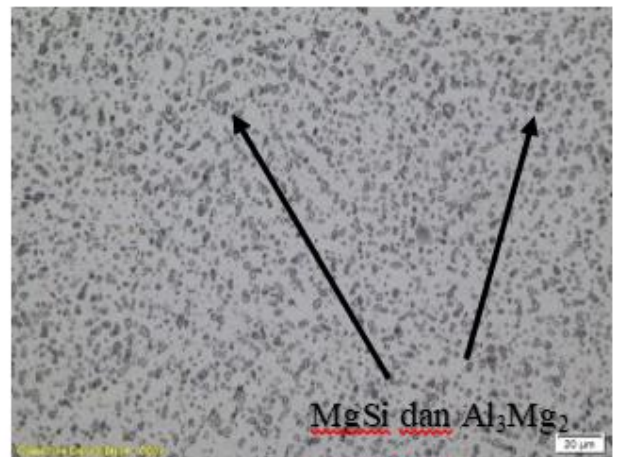

Pembesaran $500 \mathrm{x}$

Gambar 11. Struktur mikro pada Weld Metal

Dari gambar 9 daerah base metal muncul partikel $\mathrm{Al}_{3} \mathrm{Mg}_{2}$ yang dimana partikel tersebut berwarna hitam yang terpisah dari matrik aluminium yang membuat material aluminium ulet atau tangguh. Sedangkan bila semakin banyak partikel ini akan memiliki ketahanan korosi yang sangat baik yang disebut hidronallium. Demikian juga di daerah $H A Z$ muncul partikel berbentuk butir yang relatif banyak. Hal ini merupakan efek dari proses pengelasan yang menyebabkan perubahan struktur mikro berbentuk lamelar (lonjong) menjadi bentuk bulat. Perubahan ini dikarenakan kenaikan suhu kuat arus yang menyebabkan perubahan bentuk struktur mikro. Daerah weld metal terdapat warna hitam dan abu-abu yang merupakan struktur $\mathrm{MgSi}$ dan $\mathrm{Al}_{3} \mathrm{Mg}_{2}$ yang bercampur rata akibat perubahan panas sehingga partikel tersebut melebur sama rata [16].

\section{SIMPULAN.}

Untuk mengetahui pengaruh variasi sudut yang berbeda pada pengelasan MIG (metal inert gas) terhadap sifat mekanis yang menggunakan AWS A5.10 ER5183. Dari hasil penelitian dapat disimpulkan bahwa perbandingan kuat Impact dari sudut kampuh $60^{\circ}, 70^{\circ}, 80^{\circ}, 90^{\circ}$, dengan kuat Impact rata-rata $0.42 \mathrm{~J} / \mathrm{mm}^{2}$, yang diperoleh dari sudut kampuh $60^{\circ}$. Adapun pengujian hardness vickers di bagian weld metal nilai rata-ratanya, yaitu $74.75 \mathrm{HV}$ dan nilai kekerasan tertinggi di base metal bagian kanan dengan nilai rata-ratanya, yaitu 88.325 HV. Maka dapat disimpulkan bahwa base metal tidak terpengaruh perubahan temperatur. Sedangkan di bagian weld metal terkena perubahan temperatur. Pengujian Metalografi pada bagian base metal terdapat partikel $\mathrm{Al}_{3} \mathrm{Mg}_{2}$ adalah partikel hitam yang terpisah merata pada matrik aluminium yang cenderung membuat material semakin ulet atau tangguh. Daerah heat effective zone (HAZ) memiliki bentuk butir yang relatif bulat hal ini merupakan efek dari pengaruh panas proses pengelasan yang menyebabkan perubahan bentuk struktur mikro dari base metal yang semula berbentuk lamelar (lonjong), menjadi bentuk bulat. Pada daerah 
weld metal terdapat partikel-partikel baru berwarna hitam dan abu-abu yang merupakan struktur dari $\mathrm{MgSi}$ dan $\mathrm{Al}_{3} \mathrm{Mg}_{2}$ yang bercampur rata akibat perubahan panas sehingga partikel tersebut melebur sama rata.

\section{REFERENSI}

[1] Y. Winardi, F. Fadelan, M. Munaji, and W. N. Krisdiantoro, "Pengaruh Elektroda Pengelasan Pada Baja AISI 1045 Dan SS 202 Terhadap Struktur Mikro Dan Kekuatan Tarik,” J. Pendidik. Tek. Mesin Undiksha, vol. 8, no. 2, p. 86, 2020, doi: 10.23887/jptm.v8i2.27772.

[2] I. S. Anjis Ahmad Soleh, Helmy Purwanto, "Analisa Pengaruh Kuat Arus Terhadap Struktur Mikro, Kekerasan, Kekuatan Tarik Pada Baja Karbon Rendah Dengan Las Smaw Menggunakan Jenis Elektroda E7016," J. Ilm. Cendekia Eksakta, vol. 1, no. 2, pp. 29-35, 2017.

[3] A. Januar and D. Suwito, "Kajian Hasil Proses Pengelasan MIG dan SMAW pada Material ST41 dengan Variasi Media Pendingin (Air, Collent, dan Es) Terhadap Kekuatan Tarik," $J$. Tek. Mesin, vol. 4, no. 2, pp. 37-42, 2016.

[4] C. Sutowo and I. Budiawan, "ANALISA PENGARUH PENGELASAN TIG DAN MIG PADA SAMBUNGAN LAS DENGAN MATERIAL TIPE SS316 DAN SS304,” pp. 46-57.

[5] CV. JAVA MULTI MANDIRI (JVM), "Metode Pengujian Brinnell \& Vickers," vol. 2, pp. 1325, 2016, [Online]. Available: https://novotest.id/metode-pengujian-brinnell-vickers/.

[6] P. Seminar, N. Tahunan, T. Mesin, and S. Xv, "Influence of Angle Torch Position to Physical and Mechanical Properties on TIG Weld Joint of Material AA 5083 H116 and Electrode ER 5356," no. Snttm Xv, pp. 5-6, 2016.

[7] P. S. Ke-, "tanpa batas dan tanpa kehilangan karakteristik superior nya serta merupakan pertimbangan utama untuk pemanfaatan aluminium selanjutnya, mewakili salah satu atribut kunci dari keberadaan logam. Seperti dikatakan H. Amini Mashadi, dkk, bahwa daur ulang," vol. 12, pp. 97-104, 2014.

[8] T. D. S, “ANALISIS KOMPOSISI KIMIA DAN KEKERASAN MATERIAL STANDAR AlSi12(b) DARI SKRAP ALUMINIUM YANG BERBEDA,” vol. 10, no. 2, pp. 53-62, 2019.

[9] A. Pengelasan, A. Paduan, and K. Impak, "PENGARUH ARUS PROSES LAS TIG TERHADAP KEKUATAN IMPAK DAN KETAHANAN KOROSI,” pp. 1-6, 2006.

[10] Adi Nugroho, "KEKUATAN TARIK DAN KEKERASAN SAMBUNGAN LAS PLATE Email : aaddinugroho@gmail.com Jurnal Rekayasa Sistem Industri," Adi Nugroho, vol. 3, no. 2, pp. 134-142, 2018.

[11] Y. Rizal, P. T. Mesin, and U. P. Pengaraian, "Pengaruh perlakuan panas terhadap sifat kekerasan (hardness) pada roda gigi tarik sepeda motor honda 1\&2)," pp. 139-144, 1995.

[12] W. Wilarso, T. Wibowo, B. Teguh, and M. Mujiarto, "Analysis of injector spring damage to determine maintenance management diesel engine at PLTD Ampenan," J. Phys. Conf. Ser., vol. 1402, no. 7, 2019, doi: 10.1088/1742-6596/1402/7/077043.

[13] P. T. Iswanto and R. A. Himarosa, "KARAKTERISASI SAMBUNGAN SMAW BAJA KARBON RENDAH MENGGUNAKAN 3 JENIS ELEKTRODA," vol. 1, no. 2, pp. 103-109, 2017.

[14] P. Perkapalan and N. Surabaya, "Perubahan Struktur Mikro, Tegangan Sisa dan Distorsi Pada Aluminium Akibat Heat Input Proses Pengelasan GMAW Gathot Dwi Winarto *, Subowo dan Sutikno," no. Snttm Xi, pp. 16-17, 2012.

[15] D. Variabel, S. Cetakan, L. Dies, A. Wisnujati, and C. Sepriansyah, "ANALISIS SIFAT FISIK DAN MEKANIK PADUAN ALUMINIUM DERAJAT CELCIUS UNTUK MANUFAKTUR POROS BERULIR,” vol. 7, no. 2, pp. 159-165, 2018. 
Joni Arif, Koswara

PENGARUH VARIASI SUDUT KAMPUH V TERHADAP SIFAT MEKANIS PADA

SAMBUNGAN LAS ALUMINIUM 5083 ENGINE GIRDER KAPAL LAUT

[16] A. S. Nugroho et al., "PENGARUH PROSES NORMALIZING TERHADAP NILAI KEKERASAN DAN," vol. 2, no. 3, pp. 249-257, 2014. 